\title{
Maria J. Turos, Dominique Jean Larrey (1766-1842) chirurg wielkiej armii, Wydawnictwo Napoleon V, Oświęcim 2017, ss. 295 (rec. Bożena Urbanek)
}

Wieloletnie zainteresowania, ba nawet pasje Marii J. Turos ${ }^{1}$ członka Muzeum Wojskowej Służby Zdrowia w Paryżu, pracownika naukowego Warszawskiego Uniwersytetu Medycznego, zaowocowały ciekawą, a jakże potrzebną w polskiej historiografii monografią. Poświęcona została wybitnej postaci - chirurgowi armii napoleońskiej Dominikowi Jeanowi Larreyowi - powiązanemu z losami Polaków, uczestnikami wypraw Napoleona Bonapartego. Dodać bowiem warto, że do tej pory postać Larreya, według Bonapartego jedynego, któremu mógł on w pełni zaufać ${ }^{2}$, o czym przypomniała Autorka, nie doczekała się w języku polskim szerszej prezentacji. Podejmowano, co prawda, niektóre wątki jego medycznej działalności, opisywał je w swoich pracach m.in. Wiesław Stembrowicz ${ }^{3}$. Jednak dopiero po przeszło 170 latach od śmierci Larreya przyszło nam poznać jego sylwetkę - chirurga „wielkiej armii”, którego praca i poświęcenie, a przede wszystkim troska o pacjentów i rannych zaimponowała nie tylko cesarzowi Francuzów, ale także jego wrogom.

Maria Turos opisała zresztą drogę życiową Larreya, lekarza pochodzącego z Beaudean, niewielkiego miasteczka położonego u stóp Pirenejów, w sposób niezwykle dokładny i ciekawy. Książka napisana została wręcz w „beletrystyczny” sposób, nie jest jednak, pomimo pozorów, wyłącznie opowieścią. Oparta bowiem została na bardzo wnikliwej kwerendzie dokonanej w archiwach, bibliotekach francuskich, brytyjskich i polskich. Można rzec nadto, że jest to wręcz benedyktyńska praca. Autorka poszukiwała różnych źródeł informacji o tej

\footnotetext{
${ }^{1}$ M.J. Turos jest dość częstym „gościem” na łamach „Medycyny Nowożytnej”, gdzie pisze o medycynie epoki napoleońskiej, aczkolwiek nie tylko.

${ }^{2}$ M.J. Turos, Dominique Jean Larrey (1766-1842) chirurg wielkiej armii, Oświęcim 2017 , s. 7. Dodać wypada, że mimo podanego powyżej roku wydania książka ukazała się nakładem wydawnictwa „Napoleon V” na początku $2018 \mathrm{r}$.

${ }^{3}$ M.in. W. Stembrowicz, Dominique Jean Larrey (1766-1842) - autor pracy o ranach worka osierdziowego, „Archiwum Historii i Filozofii Medycyny” 1995, t. 58, nr 3 (tu za Autorką).
} 
postaci. Sięgnęła $w$ swych poszukiwaniach, jak pisze, do najwcześniejszych relacji o Larreyu, opinii czy też opracowań jeszcze z połowy XIX w., w tym pisanych, aczkolwiek z rzadka przez Polaków, np. dr. Adama F. Adamowicza, przewodniczącego Towarzystwa Lekarskiego Wileńskiego. Korzystała też ze szczątkowych, biograficznych danych prasowych, ogłaszanych np. w „Gazette Medicale de Paris”. Przytoczyła informacje z najstarszych polskich, ale i obcych encyklopedii, nieraz prostując te dane, jak miało to np. miejsce w przypadku błędnie podanej przez nieznanego autora roku urodzin Larreya, przytoczonej w XVI tomie Encyklopedii Powszechnej Samuela Orgelbranda. Wymienia zresztą Autorka nieomal wszystkie wydane biografie o Larreyu, niestety z powyżej podanych powodów drukowanych głównie poza granicami naszego kraju, przede wszystkim we Francji, stwierdzając przy tej okazji, że tam ,[...] każde pokolenie ma swoją [jego biografię]"5. M. Turos opierała się jednak przede wszystkim na pracach samego Larreya, w tym słynnych Mémories... z lat 1812-18416, a także innych jego publikowanych obserwacjach medycznych, a i na przeszło 70 listach, w tym prywatnych, pisanych głównie do rodziny. Zasadniczym zatem miejscem gromadzenia materiałów, jak to stwierdziła M.J. Turos, było paryskie archiwum, powiązane ze wspomnianym już Muzeum Wojskowej Służby Zdrowia (Musée du Service de Santé des Armées au Val-de Gràce). Ponadto korzystała ze zbiorów archiwum w Tarbes - Archives Dèpartementales des Hautes Pyrènèes, gdzie odnalazła sporą część korespondencji z lat 1812-1813. Poszukiwała też, jak sama pisze, „polskich śladów” Larreya, był to bowiem mało zbadany wątek jego aktywności medycznej, nieodtworzony nawet we francuskiej literaturze historycznej. Przy tej okazji, ale i podczas penetracji po archiwaliach polskich i obcych, docierała do wielu ciekawych ${ }^{7}$, rzec można drobiazgów dotyczących życia tej wyjątkowej dla chirurgii wojennej postaci.

Treść książki mieści się w 16 rozdziałach, nie licząc wprowadzenia z omówieniem zasobów źródłowych oraz zakończenia. Ponadto praca zaopatrzona została $\mathrm{w}$ aneks $\mathrm{z}$ wyrysowaniem całego rodu Larreyów, spisem ilustracji (a podkreślić warto, że w dużej mierze unikatowych). Walory naukowe publikacji podkreśla starannie przygotowana bibliografia źródeł, opracowań, filmowych adaptacji o Larreyu, ekspozycji

\footnotetext{
${ }^{4}$ Por. M.J. Turos, dz. cyt., s. 11.

5 Tamże, s. 17.

${ }^{6}$ Wykaz tych publikacji, jak i innych Autorka podała w wykazie 27 oryginalnych prac D.J. Larreya. Por. s. 269-271 recenzowanej publikacji.

${ }^{7}$ M.J. Turos, dz. cyt., s. 20.
} 
muzealnych i wreszcie stron internetowych wykorzystanych w pracy. Książka zawiera również indeks osobowy.

Rozdział pierwszy jest opisem początku drogi (i tak zresztą został zatytułowany) lekarskiej kariery Larreya. Jak stwierdziła Autorka, nie była ona łatwa, wcześnie stracił ojca, a dalszym kształceniem i jego wychowaniem, obok matki, zajął się miejscowy proboszcz, który uczył go podstaw matematyki, łaciny, j. francuskiego. Namówił go też, aby opuścił miasteczko i „ruszył w szeroki świat zdobywając wiedzę"8. Miastem jego rozwoju zawodowego stała się Tuluza, oddalona o $150 \mathrm{~km}$ od rodzinnych stron, gdzie mieszkał jego stryj, wykładowca na tamtejszym fakultecie medycznym. Larrey wykorzystał swą szansę, uzyskując tam solidne wykształcenie zarówno ogólne, jak i medyczne, szczególnie doskonaląc swe umiejętności w anatomii, jakże niezwykle przydatnej w przyszłej jego pracy chirurga. W 1786 r., czyli już w wieku 20 lat, uzyskał tytuł doktora za pracę $O$ próchnicy kości ${ }^{9}$.

Dalsze rozdziały tej ciekawej książki ukazują kolejne etapy jego życia, także zawodowego. Mianowicie rozdział II traktuje o służbie w wojsku, pierwszych doświadczeniach z udzielaniem pomocy rannym, ale i przeprowadzaniem chirurgicznych operacji. Rozdział III pod tytułem Ambulance Volante - czyli jak szybko dotrzeć z pomoca, przedstawia plany D.J. Larreya stworzenia systemu organizacji ruchomych ambulansów, usprawniających i przyspieszających pomoc rannym na polu walki ${ }^{10}$. Autorka nie tylko opisuje te pomysły, ale także ukazuje techniczne szkice pojazdów przeznaczonych do tych celów ${ }^{11}$. W kolejnym, IV rozdziale, zdawkowo nazwanym Burzliwe losu koleje, opisane zostały początki udanego życia małżeńskiego Larreya i jego pierwsze spotkanie w Tulonie z gen. Napoleonem Bonaparte ${ }^{12}$, z którym związał się już prawie na dalsze swoje życie. W Tulonie prowadził Larrey też cykl wykładów dla lekarzy wojskowych. Włączony już też został w system udzielania pomocy podczas trwania kampanii włoskiej zarazem, jak stwierdziła Autorka, pracował nad poprawą funkcjonowania systemu zabezpieczenia medycznego przez wprowadzane do armii ambulansów sanitarnych. W rozdziale V (Pod stońcem Egiptu) skoncentrowano się na opisie przebiegu kampanii w tym rejonie. W Egipcie też po raz pierwszy miał się spotkać z Polakami, Autorka opisała np. fakt udzielanej pomocy Józefowi Sułkowskiemu - adiutantowi Napoleona,

\footnotetext{
8 Tamże, s. 29.

9 Tamże, s. 34.

10 Tamże, s. 57.

${ }^{11}$ Tamże, s. 58, 63, 64-65.

12 Tamże, s. 75.
} 
kilkakrotnie rannemu w bitwie pod Salheyeh 11 sierpnia 1798 r. ${ }^{13}$ Kolejny rozdział - VI - pt. Doktorat po raz drugi odnosi się do drugiej, obronionej w 1803 r. tezy doktorskiej, na podstawie której Larrey uzyskał tytuł doktora chirurgii na liczącym się ówcześnie paryskim fakultecie medycznym. Tematyka jego dysertacji dotyczyła amputacji kończyn przeprowadzanych w warunkach polowych. M.J. Turos omawia szczegóły tej pracy ${ }^{14}$. Rozdział VII jest opisem zwycięstw Napoleona i udziałem w nich Larreya, już jako inspektora służby zdrowia. Autorka pisze także o innych wyróżnieniach i odznaczeniach, jakie wtedy uzyskał, w tym m.in. krzyża kawalerskiego Legi Honorowej ${ }^{15}$. Następny rozdział, zatytułowany $\mathrm{Na}$ polskich drogach $i$ bezdrożach, jest opisem przebiegu marszu Larreya $\mathrm{z}$ armią Napoleona na wschód i organizacji pomocy rannym na polskich ziemiach. Autorka stara się przy tej okazji prostować wiele utartych, a i błędnych opinii, m.in. „o manii” czy „upodobaniu” (?) Larreya do operowania” kończyn ${ }^{16}$. Dalsze rozdziały stanowią przebieg kolejnych, już niezwycięskich kampanii napoleońskich, w tym niezwykle trudnych dla zabezpieczenia pomocy rannym, mających miejsce zwłaszcza w Rosji. Turos zwróciła szczególną uwagę na postawę Larreya w tym czasie: pełną determinacji i poświęcenia rannym i chorym, który nieraz ryzykował własnym życiem. Poruszający $\mathrm{w}$ tym względzie wydaje się rozdział IX pt. Waterloo - o krok od śmierci, gdzie bohater tej biografii zderza się z rzeczywistością: bezwzględności nieprzyjaciela, ale i ostatecznie $z$ opinią wroga o jego postawie: ratowania potrzebujących pomimo grożącego niebezpieczeństwa i niezależnie od ich pochodzenia czy narodowości. Dodatkową pomocą, w tym wypadku ratującą mu życie, okazała się też jego rozległa, znana poza granicami Francji praktyka nauczycielska, a także nawiązane kontakty zawodowe. Zakończenie podsumowujące całość jest m.in. ukazaniem pozostałych po Larreyu pamiątek, w tym monumentów odtwarzających postać „,chirurga wielkiej armii”, nagród nazwanych jego imieniem, ale i wskazaniem dla zainteresowanych miejsca jego ostatecznego pochówku, którym jest od roku 1992 Krypta Gubernatorów paryskiego Hôtel des Invalides.

Można powiedzieć, że biografia Larreya może być nie tylko ciekawą lekturą dla historyków, miłośników epoki napoleońskiej, ale także szczególnie pouczającą dla lekarzy poszukujących swej zawodowej tradycji.

\footnotetext{
${ }^{13}$ Tamże, s. 89.

14 Tamże, s. 99-104.

15 Tamże, s. 109.

16 Tamże, s. 125.
} 